\title{
Analisis Kesulitan Siswa dalam Menyelesaikan Soal Cerita Berbasis Kemampuan Pemecahan Masalah
}

\author{
Buyung $^{1, *)}$, Sumarli ${ }^{2}$ \\ STKIP Singkawang, Singkawang, Indonesia \\ 21.buyung@gmail.com ${ }^{1}$, sumarliphysics@gmail.com ${ }^{2}$ \\ ${ }^{*}$ Corresponding author
}

\section{Kata Kunci:}

Kesulitan Belajar; Soal Cerita;

Kemampuan Pemecahan

Masalah

\begin{abstract}
ABSTRAK
Banyak siswa yang mengalami kesulitan dalam menyelesaikan soal cerita, terutama soal cerita dengan kemampuan pemecahan masalah yang meliputi tahap memahami masalah, merencanakan penyelesaian, melaksanakan rencana penyelesaian dan memeriksa kembali hasil. Tujuan dari penelitian ini adalah untuk mendeskripsikan kesulitan siswa dalam menyelesaikan soal cerita berbasis kemampuan pemecahan masalah. Metode yang digunakan dalam penelitian ini adalah metode deskriptif kualitatif. Subjek yang dijadikan sampel dalam penelitian ini adalah siswa kelas IV SD Santo Yosef Singkawang sebanyak 15 siswa. Instrumen yang digunakan berupa soal tes sebanyak 2 butir soal dan wawancara. Hasil penelitian menunjukkan bahwa siswa kesulitan dalam menyelesaikan soal cerita berbasis kemampuan pemecahan masalah yang meliputi: (1) pada tahap memahami masalah, siswa kesulitan dalam memahami maksud dari soal serta tidak menuliskan apa yang diketahui dan ditanyakan pada soal, (2) pada tahap merencanakan penyelesaian, siswa kesulitan dalam menyusun rencana penyelesaian karena belum terbiasa mengerjakan soal cerita sehingga kesulitan dalam hal mengaplikasikan konsep, (3) pada tahap menyelesaikan perencanaan, siswa mengalami kesulitan karena salah dalam menuliskan rumus pada tahap perencanaan strategi penyelesaian, sehingga hasil dari perhitungan penyelesaian juga salah, (4) pada tahap memeriksa kembali, siswa mengalami kesulitan dalam memeriksa kembali hasil pekerjaan karena tidak memberikan kesimpulan terhadap hasil pekerjaannya, tidak menyelesaikan soal dengan baik dan salah dalam hasil perhitungannya.
\end{abstract}

\section{PENDAHULUAN}

Matematika memiliki peranan penting dalam kehidupan sehari-hari, karena beberapa permasalahan kehidupan sehari-hari dapat diselesaikan dengan konsep-konsep matematika. Matematika bukanlah hanya sekedar kumpulan rumus-rumus dan perhitungan saja, tetapi dapat diterapkan dalam kehidupan sehari-hari untuk memecahkan berbagai masalah dan memenuhi kebutuhan praktis (Bhoke, 2017). Matematika adalah salah satu mata pelajaran yang dipelajari oleh siswa sejak dari Sekolah Dasar, 
Sekolah Menengah, bahkan sampai ke Perguruan Tinggi. Hal ini dimaksudkan untuk membekali siswa dengan kemampuan berpikir logis, analitis, sistematis, kritis, dan kreatif serta kemampuan bekerja sama (Permendiknas, 2006).

Penyelesaian permasalahan matematika dalam kehidupan sehari-hari biasanya disajikan dalam bentuk soal cerita. Menurut Dwidarti, Mampouw, dan Setyadi (2019), soal cerita dalam matematika merupakan soal yang dibuat dalam kalimat-kalimat bentuk cerita yang perlu diterjemahkan menjadi kalimat matematika atau persamaan matematika. Dalam menyelesaikan soal cerita, siswa harus memahami apa saja yang diketahui dari soal, apa saja yang ditanyakan, dan bagaimana cara mengubah soal cerita kedalam model matematika sehingga siswa dapat menemukan cara memecahkan masalah (Nugroho \& Sutarni, 2017). Dalam menjawab soal cerita, siswa harus memiliki kemampuan pemahaman yang baik mengenai isi soal. Karena, jika siswa salah memahami soal maka konsep yang digunakan untuk menyelesaikan soal juga akan salah.

Namun pada kenyataannya, masih banyak siswa yang mengalami kesulitan dalam menyelesaikan soal cerita terutama soal cerita dengan kemampuan pemecahan masalah. Menurut Rahmawati (2019), siswa yang mengalami kesulitan dalam menyelesaikan soal cerita dapat dilihat pada saat siswa melakukan kesalahan dalam mengubah soal cerita dalam kalimat matematika. Selain itu, hasil penelitian Utari, Wardana, dan Damayani (2019) juga menunjukkan bahwa siswa kelas IV yang berjumlah 10 siswa dari 15 siswa mengalami kesulitan belajar matematika dalam menyelesaikan soal cerita. Kesulitan belajar matematika dalam menyelesaikan soal cerita yang terjadi di kelas IV SD meliputi kesulitan memahami konsep, kesulitan dalam keterampilan, dan kesulitan memecahkan masalah. Oleh karena itu, perlu adanya strategi yang tepat dalam mengatasi kesulitan siswa dalam menyelesaikan soal cerita.

Menurut Fazzilah dan Effendy (2019), pemecahan masalah merupakan salah satu cara yang dilakukan seseorang untuk menemukan solusi dari permasalahan yang sedang dihadapi. Menurut teori Polya (Netriwati, 2016), tahapan kemampuan pemecahan terdiri dari 4 tahapan, yaitu: (1) tahap memahami masalah, (2) tahap menyusun rencana/memilih strategi, (3) tahap melaksanakan rencana/memecahkan masalah, dan (4) tahap memeriksa kembali hasil jawaban. Untuk menyelesaikan soal cerita maka siswa harus mempunyai kemampuan pemecahan masalah matematika yang baik. Menurut Hendri \& Kenedi (2018), melalui kemampuan pemecahan masalah yang baik, siswa dapat menggunakan pengetahuan dan keterampilan yang dimiliknya untuk menyelesaikan suatu permasalahan. Dengan menguasai kemampuan pemecahan masalah siswa akan terbiasa dalam memecahkan setiap masalah yang dihadapinya. Menurut Mariam et. al. (2019), kemampuan pemecahan masalah harus dimiliki setiap siswa dengan harapan, siswa terbiasa menyelesaikan atau menghadapi masalah yang diberikan oleh guru dengan berbagai bentuk permasalahan.

Setiap siswa memiliki kemampuan yang berbeda-beda, terutama kemampuan dalam menyelesaikan soal cerita berbasis kemampuan pemecahan masalah. Menurut Yuwono, Supanggih, dan Ferdiani (2018), siswa dalam membaca soal cerita memerlukan konsentrasi yang baik dalam memahami bacaan soal cerita untuk memastikan bahwa dia mengerti apa yang dibaca. Siswa juga memerlukan waktu lebih lama dalam memahami teks soal yang sulit, karena siswa harus memperhatikan, memvisualisasikan informasi untuk membantu mengingat dan mengerti dengan apa yang dibaca. Oleh karena itu, perlu adanya deskripsi lebih lanjut mengenai kesulitan siswa dalam menyelesaikan soal cerita berbasis kemampuan pemecahan masalah serta untuk menentukan strategi pembelajaran yang sesuai. Dalam hal ini, peneliti melakukan deskripsi terhadap kesulitan siswa dalam menyelesaikan soal cerita berbasis kemampuan pemecahan masalah di SD Santo Yosef Singkawang. Tujuan dari penelitian ini adalah untuk mendeskripsikan kesulitan siswa dalam menyelesaikan soal cerita berbasis kemampuan pemecahan masalah.

\section{METODE PENELITIAN}

Metode yang digunakan dalam penelitian ini adalah metode deskriptif dengan pendekatan kualitatif. 
Subjek yang dijadikan sampel penelitian adalah siswa kelas IV A SD Santo Yosef Singkawang sebanyak 15 siswa. Objek dalam penelitian ini adalah kesulitan siswa dalam menyelesaikan soal cerita berbasis kemampuan pemecahan masalah. Sumber data yang diperoleh dalam penelitian ini adalah dengan memberikan tes soal cerita berbasis kemampuan pemecahan masalah, kemudian melakukan wawancara kepada beberapa sampel terpilih. Adapun teknik analisis data yang digunakan dalam penelitian ini adalah teknik analisis interaktif yang dikembangkan oleh Miles dan Huberman (Sugiyono, 2010), yang meliputi 3 tahapan, yaitu: (1) tahap reduksi data, (2) tahap penyajian data, dan (3) tahap penarikan kesimpulan.

\section{HASIL DAN PEMBAHASAN}

\section{Hasil}

Persentase hasil jawaban siswa dalam menyelesaikan soal cerita berbasis kemampuan pemecahan masalah untuk setiap butir soal tes dari 15 siswa disajikan pada Tabel 1.

Tabel 1. Persentase Jawaban Siswa Tiap Butir Soal

\begin{tabular}{ccccc}
\hline \multirow{2}{*}{ Nomor Soal } & \multicolumn{5}{c}{ Indikator } \\
\cline { 2 - 5 } & $\begin{array}{c}\text { Memahami } \\
\text { Masalah }\end{array}$ & $\begin{array}{c}\text { Merencanakan } \\
\text { Penyelesaian }\end{array}$ & $\begin{array}{c}\text { Menyelesaikan } \\
\text { Perencanaan }\end{array}$ & $\begin{array}{c}\text { Memeriksa } \\
\text { kembali }\end{array}$ \\
\hline 1 & $11 \%$ & $38 \%$ & $31 \%$ & $11 \%$ \\
2 & $0 \%$ & $22 \%$ & $42 \%$ & $27 \%$ \\
\hline $\begin{array}{c}\text { Persentase } \\
\text { Keseluruhan }\end{array}$ & $\mathbf{6 \%}$ & $\mathbf{3 0 \%}$ & $\mathbf{3 7 \%}$ & $\mathbf{4 1 \%}$ \\
\hline
\end{tabular}

Berdasarkan Tabel 1 dapat dilihat bahwa siswa masih kesulitan dalam menyelesaikan soal cerita dengan kemampuan pemecahan masalah karena persentase pencapaian rata-rata masih dibawah 50\%. Hal ini didukung dengan beberapa hasil jawaban siswa seperti yang disajikan pada Gambar 1 sampai dengan Gambar 4.

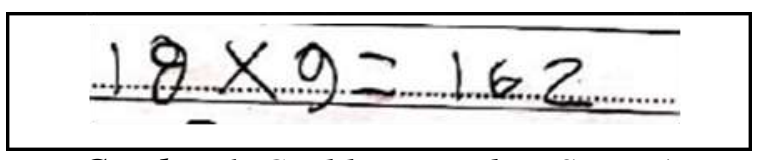

Gambar 1. Cuplikan Jawaban Siswa A

Dari jawaban siswa A pada soal nomor 1 (Gambar 1), pada tahap memahami masalah siswa tidak menuliskan apa yang diketahui dan ditanyakan dari soal. Pada tahap merencanakan penyelesaian siswa juga tidak melakukan perencanaan penyelesaian soal. Pada tahap menyelesaian perencanaan siswa melakukan perhitungan yang salah. Kemudian pada tahap memeriksa kembali, siswa tidak memberikan kesimpulan disetiap jawaban yang di kerjakan.$$
\text { Diketahui } P=18 \mathrm{~m} 1=9 \mathrm{~m} n=\Omega \text { KaLi } \Omega \times a(P+D)
$$

Gambar 2. Cuplikan Jawaban Siswa B

Dari jawaban siswa B pada soal nomor 1, pada tahap memahami masalah siswa telah menuliskan apa yang diketahui dari soal. Pada tahap merencanakan penyelesaian siswa juga melakukan perencanaan penyelesaian soal dengan menuliskan rumus yang digunakan untuk penyelesaian. Pada tahap menyelesaian perencanaan siswa tidak melakukan perhitungan, padahal formula yang ditulis sudah benar. Kemudian pada tahap memeriksa kembali, siswa tidak memberikan kesimpulan disetiap jawaban yang di kerjakan. 


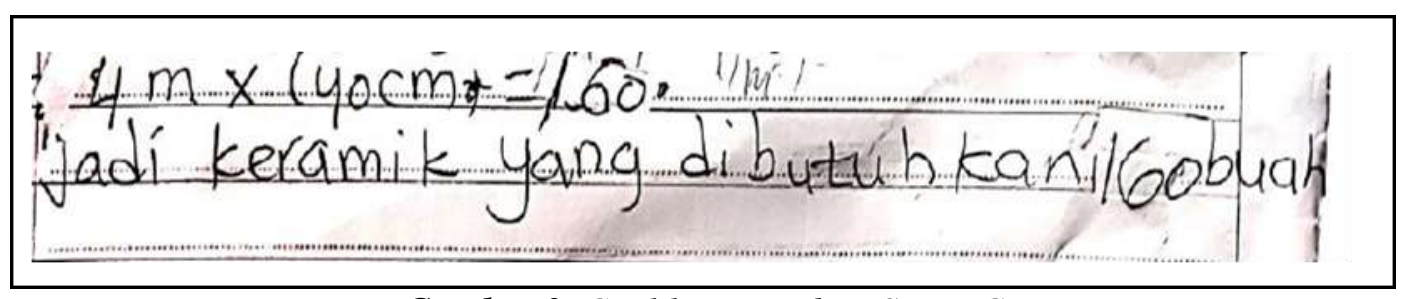

Gambar 3. Cuplikan Jawaban Siswa C

Dari jawaban siswa C pada soal nomor 2, pada tahap memahami masalah siswa tidak mampu menuliskan apa yang diketahui dan ditanyakan dari soal. Kemudian pada tahap merencanakan penyelesaian, siswa tidak menuliskan perencanaan atau konsep rumus dalam pengerjaannya. Siswa melakukan penyelesaian dan memberikan kesimpulan dari pekerjaannya, akan tetapi hasil yang diperoleh salah.

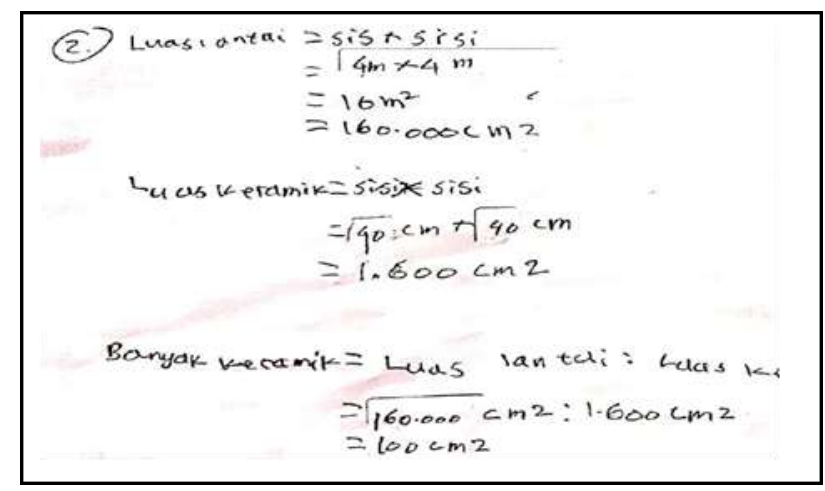

Gambar 4. Cuplikan Jawaban Siswa D

Dari jawaban siswa D pada soal nomor 2, pada tahap memahami masalah siswa tidak mampu menuliskan apa yang diketahui dan ditanyakan dari soal. Kemudian pada tahap merencanakan penyelesaian, siswa menuliskan perencanaan atau konsep rumus dalam pengerjaannya, yaitu dengan menggunakan rumus luas persegi akan tetapi siswa salah memahami rumus tersebut dengan memberikan akar pada pengerjaannya. Pada tahap menyelesaikan perencanaan siswa melakukan penyelesaian dengan benar, akan tetapi pada tahap memeriksa kembali siswa tidak memberikan kesimpulan.

\section{Pembahasan}

Dari beberapa hasil cuplikan jawaban siswa dan hasil analisis menunjukkan bahwa siswa kesulitan dalam menyelesaikan soal cerita berbasis kemampuan pemecahan masalah yang meliputi: tahap memahami masalah, merencanakan penyelesaian, melaksanakan rencana penyelesaian, dan memeriksa kembali hasil. Pada tahap memahami masalah, dari 4 subjek hasil penelitian yang dipilih secara random untuk dianalisis tersebut menunjukkan bahwa siswa masih kesulitan dalam memahami maksud dari soal tersebut. Ini terlihat dari siswa tidak menuliskan apa yang diketahui dan ditanyakan dari soal. Dari 15 subjek yang diteliti, hanya 6\% siswa yang mampu memahami masalah. Hal ini sejalan dengan penelitian Sulistyorini \& Setyaningsih (2016) bahwa siswa kesulitan memahami masalah karena siswa tidak biasa mengerjakan soal cerita dengan langkah pemecahan masalah. Selain itu, menurut Ardiyanti et al. (2019:395), kesulitan siswa dalam memahami masalah disebabkan karena siswa tidak memahami maksud soal.

Pada tahap merencanakan penyelesaian, persentase keseluruhan siswa yang mampu merencanakan penyelesaian hanya $30 \%$. Faktor yang menyebabkan siswa kesulitan dalam menyusun rencana penyelesaian adalah karena siswa kesulitan dalam memahami masalah. Jika hal ini terjadi maka siswa juga akan kesulitan dalam menentukan strategi penyelesaian yang sesuai. Hal tersebut apat dilihat dari hasil jawaban siswa yang tidak menuliskan rumus penyelesaian, ini mungkin terjadi karena siswa tidak terbiasa dalam mengerjakan soal cerita sehingga kesulitan dalam mengaplikasikan konsep serta siswa 
tidak mampu mengubah soal cerita menjadi kalimat matematika. Hal ini sejalan dengan penelitian Sulistyorini \& Setyaningsih (2016) yang mengemukakan bahwa kesulitan pada aspek membuat rencana yaitu kemampuan siswa yang rendah dalam memahami masalah dan kurangnya latihan soal.

Pada tahap menyelesaikan perencanaan, secara keseluruhan hanya $37 \%$ siswa yang mampu menyelesaikan perencanaan yang dilakukan. Hal ini terjadi karena siswa salah dalam menuliskan rumus pada tahap perencanaan strategi penyelesaian, sehingga hasil dari perhitungan penyelesaian juga salah. Hasil penelitian Sulistyorini \& Setyaningsih (2016) juga menunjukkan bahwa kesulitan siswa pada aspek melaksanakan rencana terjadi karena kebiasaan siswa kurang teliti dalam perhitungan, langkah-langkah terlalu panjang, dan salah dalam menuliskan rumus.

Pada tahap memeriksa kembali, hanya $41 \%$ siswa yang mampu memeriksa kembali hasil pekerjaannya. Siswa kesulitan dalam memeriksa kembali hasil pekerjaan karena tidak memberikan kesimpulan terhadap hasil pekerjaannya, tidak menyelesaikan soal dengan baik, dan salah dalam hasil perhitungannya. Siswa juga kurang memahami bahwa ketika mengerjakan soal cerita maka diakhir jawaban harus menyertakan kesimpulan. Hasil penelitian Sulistyorini \& Setyaningsih (2016) juga menunjukkan bahwa kesulitan pada aspek memeriksa kembali adalah siswa tidak tahu cara melihat kembali yang benar, siswa tidak dapat mengatur waktu pengerjaan dengan baik, dan sikap malas siswa mengecek ulang jawaban.

Analisis hasil pekerjaan siswa juga didukung oleh hasil wawancara terhadap siswa bahwa mereka tidak terbiasa dalam mengerjakan soal cerita dan tidak diajarakan tahapan-tahapan dalam kemampuan pemecahan masalah. Hal ini yang menyebabkan siswa kesulitan dan tidak memahami soal yang diberikan serta bingung menggunakan rumus yang akan digunakan.

\section{KESIMPULAN}

Berdasarkan hasil penelitian dan pembahasan, dapat disimpulkan bahwa kemampuan siswa dalam menyelesaikan soal cerita berbasis kemampuan pemecahan masalah masih kurang. Pada tahap memahami masalah, siswa kesulitan dalam memahami maksud dari soal. Terlihat dari siswa yang tidak menuliskan apa yang diketahui dan ditanyakan dari soal. Pada tahap merencanakan penyelesaian, siswa kesulitan dalam menyusun rencana penyelesaian karena siswa kurang dalam memahami masalah dan tidak terbiasa mengerjakan soal cerita sehingga kesulitan dalam mengaplikasikan konsep, serta siswa tidak mampu mengubah soal cerita menjadi kalimat matematika. Pada tahap menyelesaikan perencanaan, siswa mengalami kesulitan karena salah dalam menuliskan rumus pada tahap perencanaan strategi penyelesaian sehingga hasil dari perhitungan penyelesaian juga salah. Pada tahap memeriksa kembali, siswa kesulitan dalam memeriksa kembali hasil pekerjaan karena tidak memberikan kesimpulan terhadap hasil pekerjaannya serta tidak menyelesaikan soal dengan baik dan salah dalam hasil perhitungannya. Dari hasil wawancara juga menyatakan bahwa siswa kurang mampu memahami soal cerita dan tidak terbiasa mengerjakan soal cerita, sehingga kesulitan dalam melakukan perhitungan yang tepat.

\section{DAFTAR PUSTAKA}

Aminah, A. \& Kurniawati, K.R.A. (2018). Analisis Kesulitan Siswa dalam Menyelesaikan Soal Cerita Matematika Topik Pecahan Ditinjau dari Gender. JTAM (Jurnal Teori dan Aplikasi Matematika), 2(2), 118-122.

Ardiyanti, S. et al. (2019). Analisis Kesulitan Siswa dalam Menyelesaikan Soal Cerita pada Materi Teorema Phythagoras Ditinjau dari Pemecahan Masalah Polya. Prosiding Seminar Nasional Pendidikan Matematika, 389-398.

Bhoke, W. (2017). Hubungan Antara Berprestasi dengan Hasil Belajar Matematika pada Siswa Kelas IV SD Gugus V Kecamatan Mauponggo. Jurnal Ilmiah Pendidikan, 4(1), 29-43. 
Dwidarti, U., Mampouw, H.L., \& Setyadi, D. (2019). Analisis Kesulitan Siswa dalam Menyelesaikan Soal Cerita pada Materi Himpunan. Jurnal Cendekia: Jurnal Pendidikan Matematika, 3(2), 315-322.

Fazzilah, E., \& Effendi, K.N. (2019). Strategi Pemecahan Masalah Siswa Kelas VIII pada Soal PISA Like. Prosiding Seminar Nasional Matematika dan Pendidikan Matematika, 883-891.

Hendri, S., \& Kenedi, A.K. (2018). Pengembangan Perangkat Pembelajaran Matematika Berbasis Discovery Learning untuk Meningkatkan Kemampuan Pemecahan Masalah Siswa Kelas VIII SMP. Jurnal Inspirasi Pendidikan, 8(2), 10-24.

Mariam, S., Nurmala, N., Nurdianti, D., Rustyani, N., Desi, A., \& Hidayat, W. (2019). Analisis Kemampuan Pemecahan Masalah Matematis Siswa MTsN dengan Menggunakan Metode Open Ended di Bandung Barat. Jurnal Cendekia: Jurnal Pendidikan Matematika, 3(1), 178186.

Netriwati, N. (2016). Analisis Kemampuan Mahasiswa dalam Pemecahan Masalah Matematis Menurut Teori Polya. Al-Jabar: Jurnal Pendidikan Matematika, 7(2), 181-190.

Nugroho, R.A., \& Sutarni, S. (2017). Analisis Kesulitan Siswa dalam Menyelesaikan Soal Cerita pada Materi Pecahan Ditinjau dari Pemecahan Masalah Polya. Electronic Thesis and Dissertations. Universitas Muhammadiyah Surakarta.

Permendiknas. (2006). Peraturan Menteri Pendidikan Nasional Republik Indonesia Nomor 22 Tahun 2006 tentang Standar Isi untuk Satuan Pendidikan Dasar dan Menengah, Lampiran. Jakarta: Menteri Pendidikan Nasional.

Putri, D.A., Winarni, R., \& Surya, A. (2021). Analisis Kesulitan Belajar Pemecahan Masalah Matematika Berdasarkan Newman Procedure pada Peserta Didik Kelas V Sekolah Dasar. Didaktika Dwija Indria, 9(3).

Rahmawati, A. (2019). Analisis Kesulitan Siswa dalam Menyelesaikan Soal Cerita Matematika Berbasis Pembelajaran Pemecahan Masalah Kelas V SD Negeri Gebangsari 03. Jurnal Pengembangan Pembelajaran Matematika, 1(2), 46-51.

Sugiyono. (2010). Statistika untuk Penelitian. Bandung: Alfabeta.

Sulistyorini, S., \& Setyaningsih, N. (2016). Analisis Kesulitan Siswa dalam Pemecahan Masalah Soal Cerita Matematika pada Siswa SMP Kelas VII di SMPN 2 Gatak Sukoharjo. Doctoral Dissertation. Universitas Muhammadiyah Surakarta.

Utari, D.R., Wardana, M.Y.S., \& Damayani, A.T. (2019). Analisis Kesulitan Belajar Matematika dalam Menyelesaikan Soal Cerita. Jurnal Ilmiah Sekolah Dasar, 3(4), 534-540.

Yuwono, T., Supanggih, M., \& Ferdiani, R.D. (2018). Analisis Kemampuan Pemecahan Masalah Matematika dalam Menyelesaikan Soal Cerita Berdasarkan Prosedur Polya. Jurnal Tadris Matematika, 1(2), 137-144. 